\title{
Variations in the
}

Chemical Character of the

\section{Susquehanna River at}

Harrisburg, Pennsylvania

GEOLOGICAL SURVEY WATER-SUPPLY PAPER 1779-B

Prepared in cooperation with the Pennsylvania Department of Forests and Waters and the Pennsylvania Department of Commerce

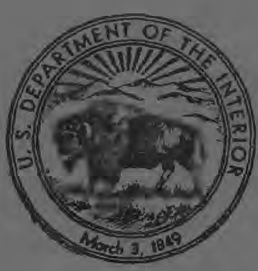




\section{Tariations in the}

Themical Character of $t$ the usquehanna River at

\section{Harrisburg, Pennsylvania}

PETER W. ANDERSON

C NTRIBUTIONS TO THE HYDROLOGY OF THE UNITED STATES

OOLOGICAL SURVEY WATER-SUPPLY PAPER 1779-B

"epared in cooperation with the Pennivania Department of Forests and Taters and the Pennsylvania Depart:ent of Commerce

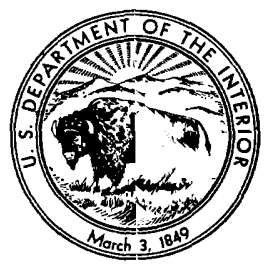


UNITED STATES DEPARTMENT OF THE IN'?ERIOR

STEWART L. UDALL, Secretary

\section{GEOLOGICAL SURVEY}

Thomas B. Nolan, Director

For sale by the Superintendent of Documents, U.S. Government. Printing Office Washington, D.C. 20402 


\section{CONTENTS}

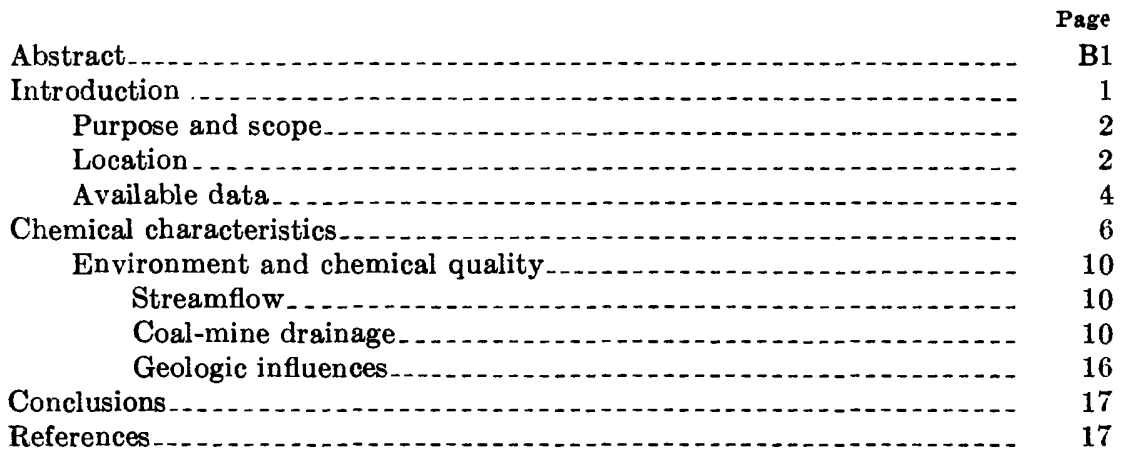

\section{ILLUSTRATIONS}

FIGURE 1. Cross-section sampling stations

2. Cross-section diagram

3. Average bicarbonate- and sulfate-ion concentrations..........

4. Specific conductances - .

5. Susquehanna River basin

6. Sulfate- and bicarbonate-ion concentrations.............. 13

\section{TABLES}

$T_{A B L E}$ 1. Percent of days in which physical and chemical properties were equaled or exceeded, Susquehanna River at Harrisburg, Pa., station E. 1180

2. Maximum, average, and minimum observed values for specific conductance, $\mathrm{pH}$, and chemical analyses, Susquehanna River at Harrisburg, Pa., October 1956 to September 1960 (based on once-a-month sampling)

3. Physical and chemical character of mine drainage from anthracite coal fields, collected June 25,1959

4. Chemical analyses, in parts per million, at sampling stations in the Susquehanna River basin, Pennsylvania

5. Chemical analyses, in parts per million, at cross-sectior sampling locations on the Susquehanna River in Pennsylvania, collected July19, 1961 



\title{
CONTRIBUTIONS TO THE HYDROLOGY OF THE UNITED STATES
}

\section{VARIATIONS IN THE CHEMICAL CHARAGTER OF THE SUSQUEHANNA RIVER AT HARRISBURG, PENNSYLVANIA}

\author{
By Peter W. Anderson
}

\section{ABSTRACT}

The chemical quality of the Susquehanna River at Harrisburg is influenced by three major factors: streamflow, anthracite and bituminus coal-mine drainage, and geology. Water samples collected at Harrisburg near the west bank of the Susquehanna River and those of western tributaries that drain limestone terranes are similar in chemical quality. The water is alkaline and contains calcium, magnesium, and bicarbonate-ion concentrations typical of water drained from limestone. The chemical quality of water samples collected in the center of the river resembles the quality of the West Branch Susquehanna Riv?r, which has a dissolved-solids content of about 200 parts per million, and a sulfate-ion concentration that generally exceeds the bicarbonate-ion concentration. Samples collected near the east or Harrisburg bank show the effect of anthracite coalmine drainage from the river's eastern tributaries. The $\mathrm{pH}$ of these samples ranges from 5.7 to 7.5, and sulfate is the predominate ion.

The dissolved-solids content of the river at the Harrisburg cross-section stations is inversely proportional to the streamflow. During periods of low riverflow, the dissolved-solids content approaches a maximum; during perioc's of high flow, the content is low.

The chemical composition of the river at the Harrisburg cross section indicates that water from the principal tributaries above Harrisburg does not mix sufficiently to lose its chemical-quality identity before reaching Harrisburg irrespectire of the long distance involved, the many islands and bridge piers. and the rough streambed. This lack of lateral mixing is probably due to the small depth-width ratio and the extreme width of the river.

\section{INTRODUCTION}

A reconnaissance of the Susquehanna River at Harrisburg in 1944 indicated a wide variation in chemical quality across the width of the river. Because a single sample would not be representative of the water quality of the river, the U.S. Geological Survey, the Pennsylvania Department of Forests and Waters, and the Pennsylvania Department of Commerce cooperated to investigate the variations in 
chemical quality of the river from bank to bank. Samples generally were taken at six stations in the cross section on the Walnut Street bridge in Harrisburg.

\section{PURPOSE AND SCOPE}

This report describes the variations in chemical quality of the Susquehanna River at Harrisburg, discusses the causative factors involved, and shows how they influence the chemical character of the river. The Harrisburg location was selected for study because of its marked cross-section variation in chemical quality and because of the considerable interest in the chemical quality of the river water, shown by representatives in the fields of water management and public water supplies.

This report summarizes the data collected during the period 1944-60 at the Harrisburg location. Variations in the chemical quality across the river are described in terms of these data. A qualitative interpretation of the chemical analyses collected at several locations on the Susquehanna River main stem and its tributaries shows the effects of physiographic, hydrologic, and cultural environment on the chemical character of the river at Harrisburg.

\section{LOCATION}

The Susquehanna River originates in Otsego Lake in southeastern New York State, enters Pennsylvania near Lanesboro, Susquehanna County, reenters New York State near Great Bend, Pa., and then reenters Pensylvania near Sayre, Bradford County. From the Pennsylvania-New York State line, the river flows southward through central Pennsylvania to the Chesapeake Bay. The drainage basin of the entire river is 27,655 square miles, three-fourths of it within Pennsylvania.

The cross-section sampling stations are on the Walnut, Street bridge connecting the capital city of Harrisburg, Dauphin Ccunty, and the borough of Lemoyne, Cumberland County (fig. 1). Harrisburg is 69 miles from the mouth of the river and 353 miles from its headwaters. At the sampling station, City Island divides the river into east and west channels. At median flow the gross widths of the east and the west channels are 1,288 and 1,330 feet, respectivel 7 .

The Susquehanna River at the sampling station has a drainage area of 24,100 square miles. The median flow for the period 1891-1959 was about 20,000 cfs (cubic feet per second). A cross-section diagram of the east and west channels at the Walnut Street bridge shows the relative depth of the river at median flow (fig. 2). The depths at the cross-section sampling stations are shallow, ranging at median flow from 3.9 feet at station W. 1320 to 9.3 feet at station E. 600 . 


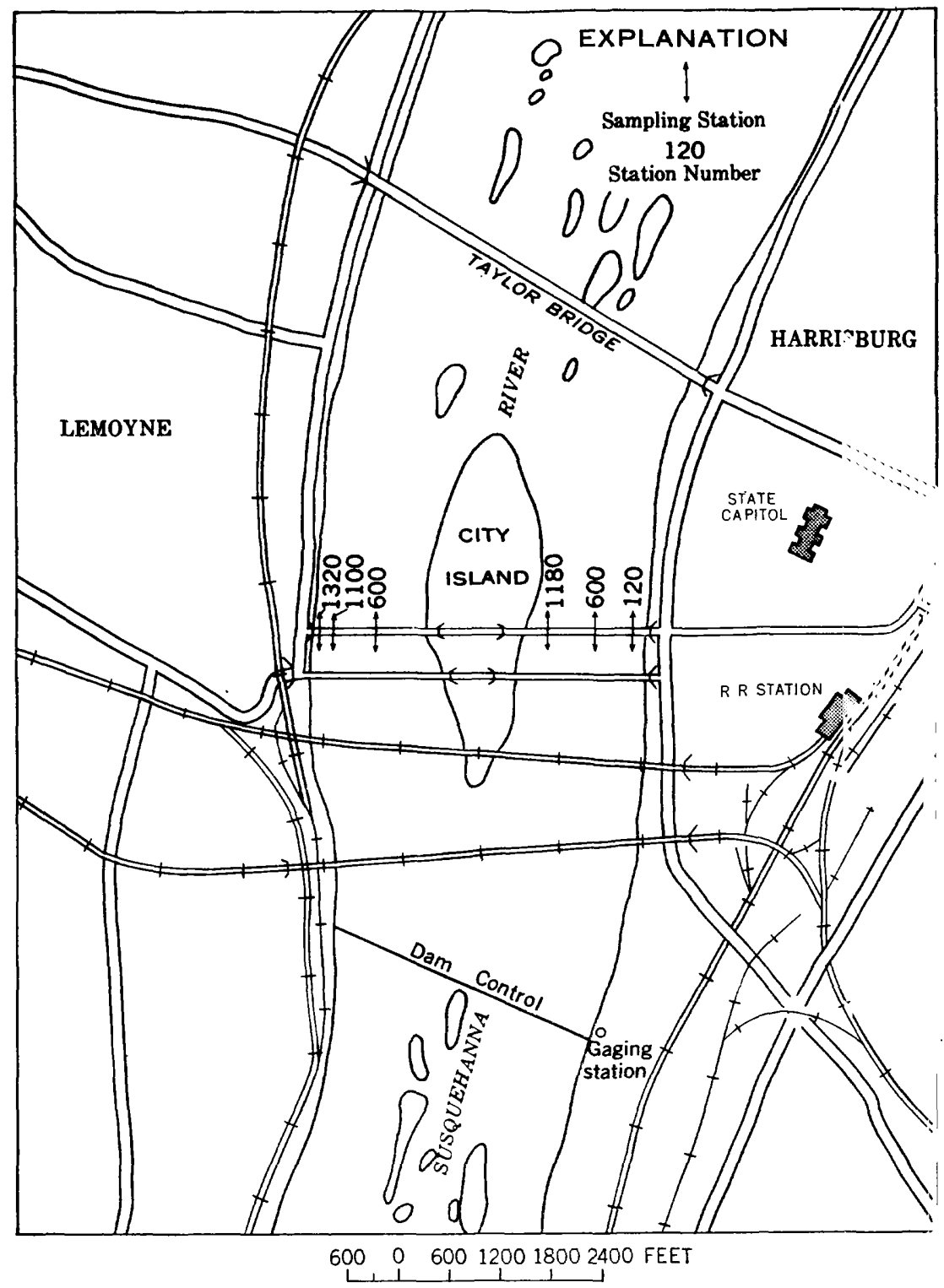

FigdRe 1.-Location of chemical quality cross-section sampling stations, Susquehanna River at Harrisburg, Pa. 


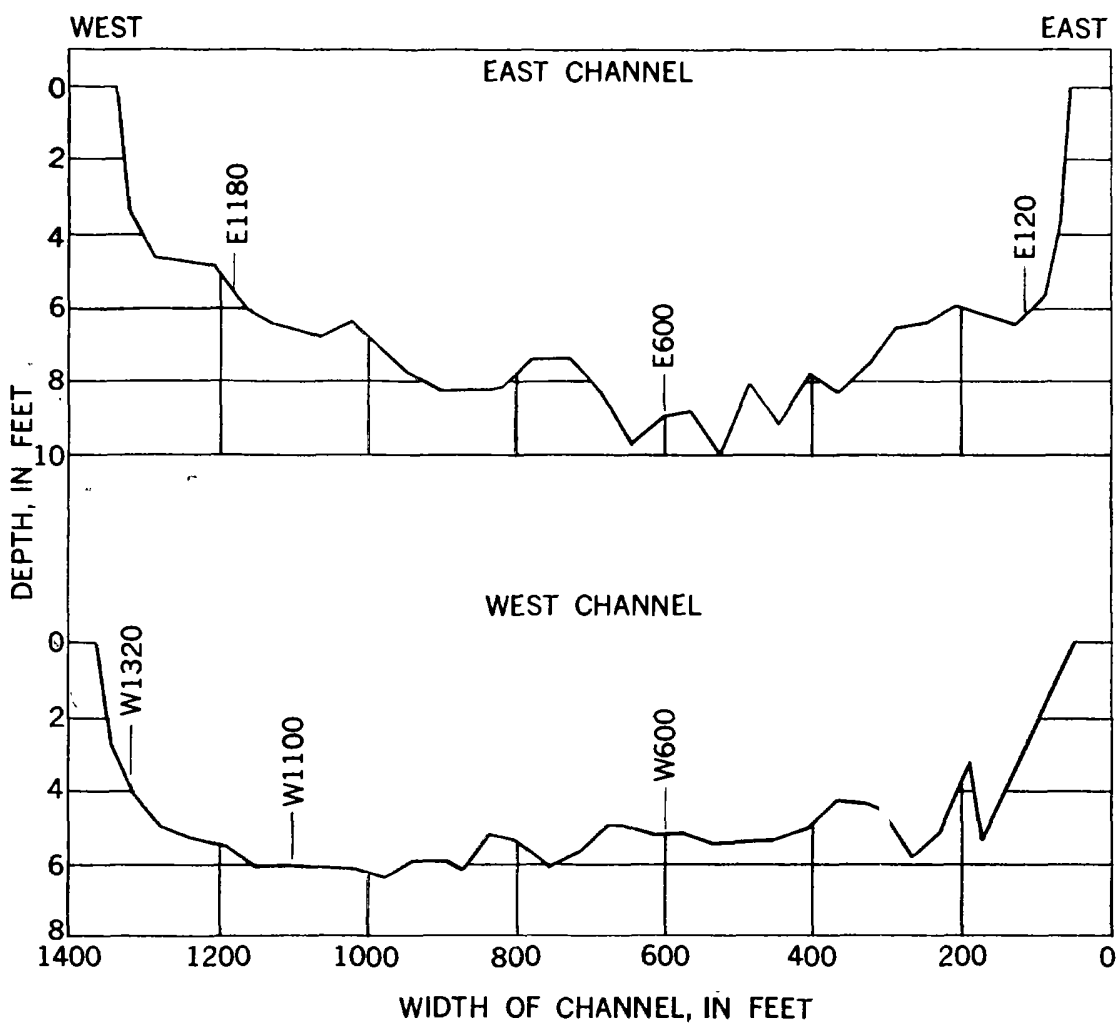

Figure 2.-Cross-section diagram of depth in the east and west. channels of the Susquehanna River at Harrisburg, Pa., on October $31,1958$.

\section{AVAILABLE DATA}

From October 1944 to September 1946, the Susquehanna River was sampled from 1 to 3 times a month at each of 11 sampling sites on the Walnut Street bridge at Harrisburg. In October 1946, the number of sampling sites was reduced to six, three ir each channel. In the east channel, samples were usually collected at 95,575 , and 1,155 feet from the east or Harrisburg bank, and in the west channel at $563,1,063$, and 1,283 feet from the west bank of City Island.

Chemical analyses of each sample consisted of the determination of color, $\mathrm{pH}$, specific conductance, bicarbonate, sulfate, chloride, nitrate, and hardness. The results of these chemical analyses from 1944 to 1951 were reported by W. F. White (1947 and 1951) and N. H. Beamer (1953). These publications of the Pennsylvania Department of Commerce contain graphs and brief comments on the Harrisburg stations.

From October 1944 to September 1946, daily water samples were collected at the east channel station E. 1180. The water of this station 
location was representative of the quality of raw water used by the former city waterworks on City Island. Temperature, $\mathrm{pH}$, and specific conductance were measured on each sample. The daily samples for each month were composited into three 10-day samples, and a comprehensive analysis was made of each. The comprehensive analysis included the determination of color, $\mathrm{pH}$, specific conductance, silica, iron, calcium, magnesium, sodium, potassium, bicarbonate, sulfate, chloride, fluoride, nitrate, dissolved solids, and hardness.

Results of the chemical-quality studies at the daily sampling station E. 1180 are summarized in a report entitled, "The Chemical Quality of Surface Water in Pennsylvania" (Durfor and Anderson, 1963). The tabulated summary of chemical analyses at this station is given in table 1. The table was prepared by the following methods: (1) frequency distributions of daily temperature, $\mathrm{pH}$, and specific conductance values were determined; (2) relations were establirhed between the specific conductance and the concentration of individual dissolved constituents of composite samples; and (3) on the basis of these empirical relations between specific conductance and ion concentration and the frequency distribution of specific conductance, the frequency distribution of several chemical constituents was estimated.

TABLE 1.-Percent of days in which physical and chemical properties were equaled or exceeded, Susquehanna River at Harrisburg, Pa., station E. 1180, October 1944 to September 1946

[Analyses by U.S. Geol. Survey]

\begin{tabular}{|c|c|c|c|c|c|}
\hline & $\stackrel{1}{\text { percent }}$ & $\begin{array}{l}10 \\
\text { percent }\end{array}$ & $\begin{array}{c}50 \\
\text { percent }\end{array}$ & $\begin{array}{l}90 \\
\text { percent }\end{array}$ & $\begin{array}{l}99 \\
\text { percent }\end{array}$ \\
\hline Temperature $\left({ }^{\circ} \mathrm{F}\right)$ & \multirow{2}{*}{$\begin{array}{r}79 \\
7.5 \\
369\end{array}$} & $\begin{array}{l}75 \\
7.2\end{array}$ & $\begin{array}{l}55 \\
6.9\end{array}$ & $\begin{array}{c}34 \\
6.6\end{array}$ & $\begin{array}{r}32 \\
6.2\end{array}$ \\
\hline $\begin{array}{l}\text { Specific conductance (micromhos at } \\
25{ }^{\circ} \mathrm{C} \text { ) }\end{array}$ & & 278 & 180 & 105 & 88 \\
\hline Chemical analyses in parts per million: & & & & & \\
\hline $\begin{array}{l}\text { Calcium (Ca) } \\
\text { Magnesium (Mg) }\end{array}$ & $\begin{array}{l}40 \\
14\end{array}$ & $\begin{array}{l}30 \\
10\end{array}$ & $\begin{array}{r}20 \\
5.9\end{array}$ & 12. 0 & ${ }^{10} .2$ \\
\hline Sodium and potassium $(\mathrm{Na}+\mathrm{K})$ & $\begin{array}{l}14 \\
48\end{array}$ & $\begin{array}{l}10 \\
40\end{array}$ & 6. 1 & 3. 0 & 1.4 \\
\hline Sulfate $\left(\mathrm{SO}_{4}\right)$ & & 00 & & 28 & 21 \\
\hline Chloride (Cl) & 9. 0 & 6. & 4. 2 & 2.4 & 2. 0 \\
\hline Residue on evaporation at $180^{\circ} \mathrm{C}$ - & 244 & 170 & 110 & 64 & 54 \\
\hline $\mathrm{CaCO}_{3}$ & 156 & 114 & 73 & 42 & 34 \\
\hline
\end{tabular}

Compilations of the chemical-quality data collected in Penncylvania since 1944 are published by the Geological Survey in the WaterSupply Paper series entitled "Quality of Surface Waters of the. United States, Parts 1-4, North Atlantic Slope Basins to St. Lawrence River Basin." The chemical quality of the Susquehanna River at Harrisburg was discussed by W. F. White (1949) in a paper presented at a meeting of the Engineers' Society of Western Pennsylvania.

695-897-63-2 


\section{CHEMICAL CHARACTERISTICS}

The principal dissolved constituents in the Susquehanna River water at Harrisburg are calcium, magnesium, sodium, silica, bicarbonate, sulfate, chloride, and nitrate. Smaller quantities of other constituents, such as potassium, iron, manganese, and fluoride are also present. The river water generally contains less than $200 \mathrm{ppm}$ (parts per million) of dissolved solids at station E. 1180 and W. 1320 and less than $325 \mathrm{ppm}$ at station E. 120 . The dissolved-solids content was estimated from the specific conductance. For water from the Susquehanna River at Harrisburg, the dissolved-solids content is approximately $0.62 \pm 0.02$ of the specific conductance.

To demonstrate the variations in chemical quality from bank to bank, a tabulation of the maximum, average, and minimum observed values for specific conductance, $\mathrm{pH}$, and chemical analyses, based on once-a-month sampling at the cross-section stations (October 1956 to September 1960), is presented in table 2. This period is chosen for tabulation because of the availability of consecutive monthly data.

The average sulfate and bicarbonate-ion concentrations compiled in table 2 are plotted in figure 3 to demonstrate the variations in concentration of these ions across the river. The bicarbonate ion decreases in concentration from 113 to $19 \mathrm{ppm}$ in a west to east direction, and the sulfate ion increases in concentration from 24 to $131 \mathrm{ppm}$. The maximum hydrogen-ion concentration $(\mathrm{pH})$ decreas $\mathrm{s}$ from 8.5 to 7.5 (table 2). The hardness of water is low near the center of the river and increases toward the banks (table 2 ). The hardness near the east bank results from the presence of calcium sulfate. Near the west bank the hardness is the result of the presence of calcium bicarbonate. 

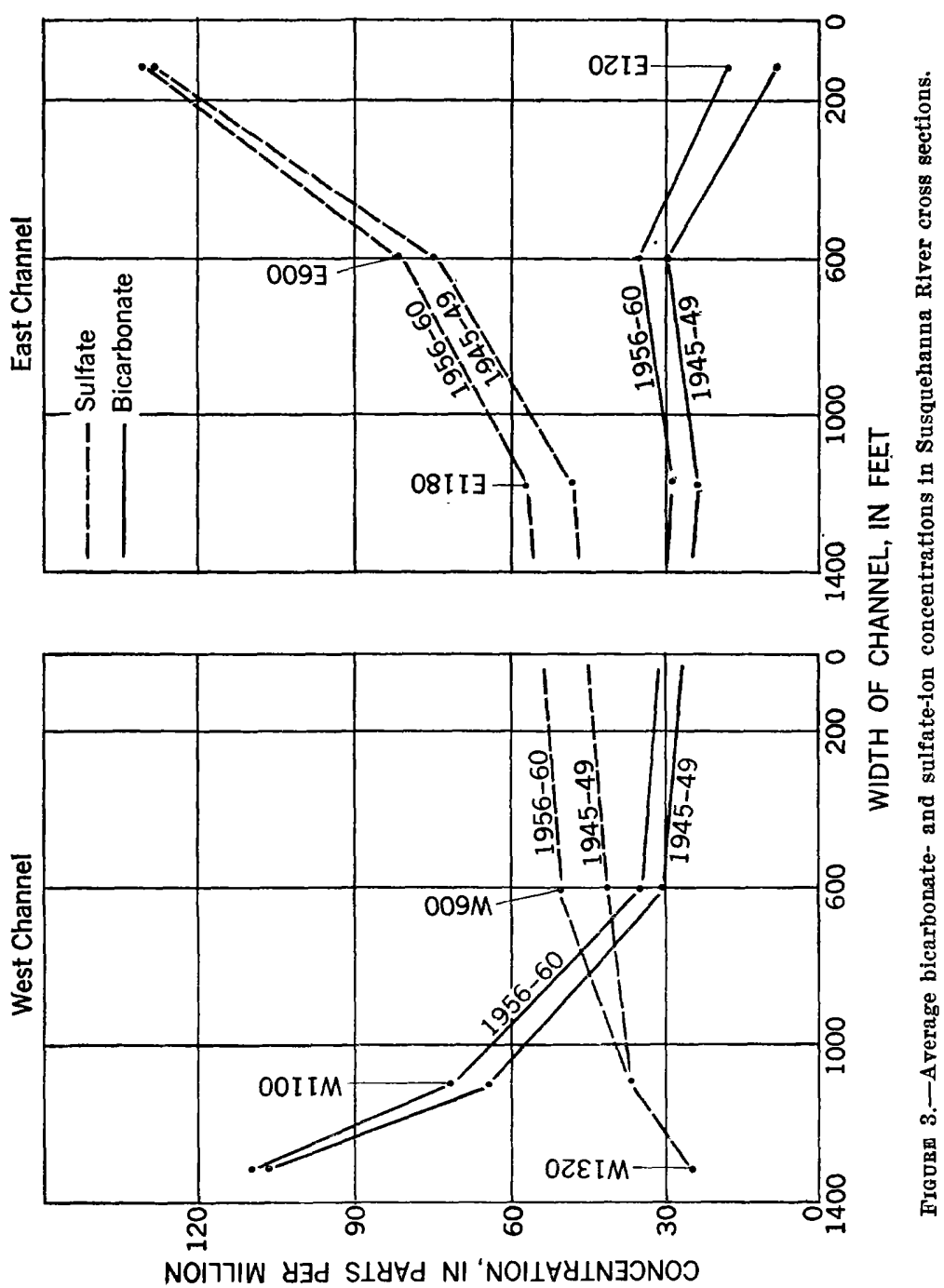
TABLE 2.-Maximum, average, and minimum observed values for speoific conductance, $p H$, and chemical analyses, Susquehanna River at Harrisburg, Pa., October 1956 to September 1960

[Analyses by U.8. Geol. Survey. Based on once-a-month sampling]

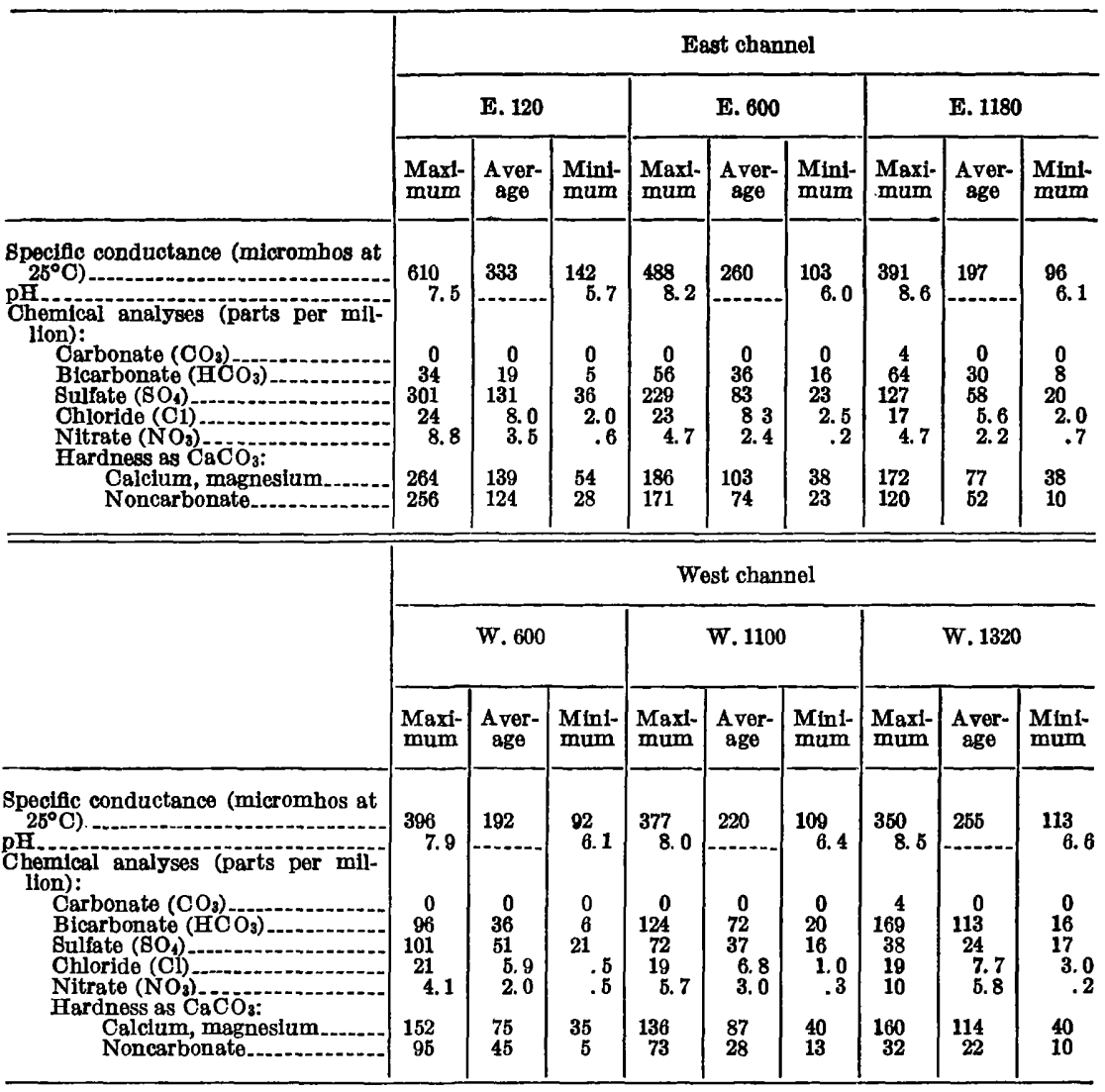

A comparison of bicarbonate, and sulfate-ion concentrations plotted in figure 3 for the 4-year periods 1956-60 and 194.5-49 indicates that the river water has changed little during the period of data collection. The mean discharge for the period 1956-60 (34,910 cfs) is slightly less than the mean discharge for the period $1.945-49(35,320$ cfs). This slight difference in discharge accounts for the slightly lower bicarbonate and sulfate concentrations during the 1945-49 period.

The variations in specific conductance and, therefore, the dissolvedsolids content from bank to bank are shown in figure 4. For both the high and the low discharge rates, the specific conduc'ance is higher near the banks than in the center. The higher conductance values are near the east or Harrisburg bank for both discharge rates. A com- 


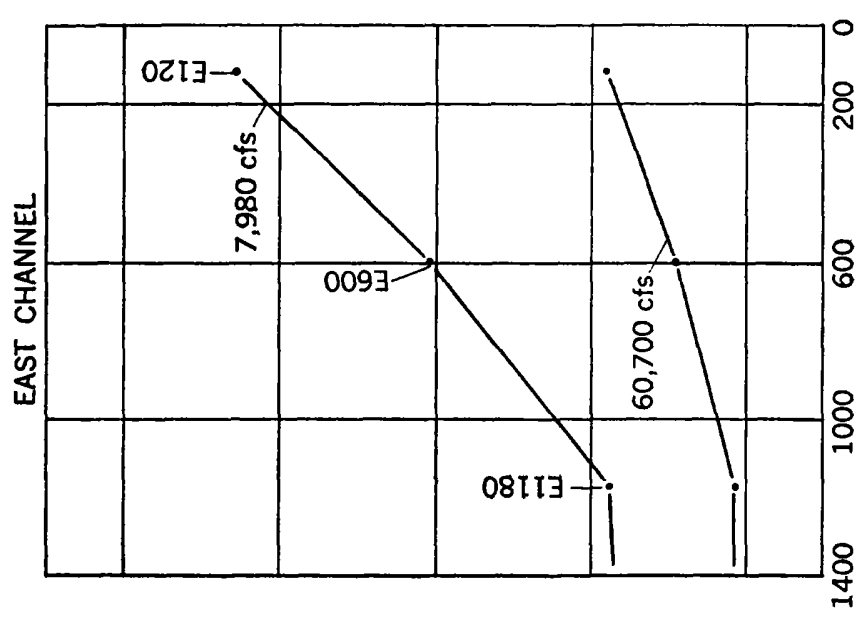

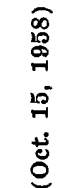

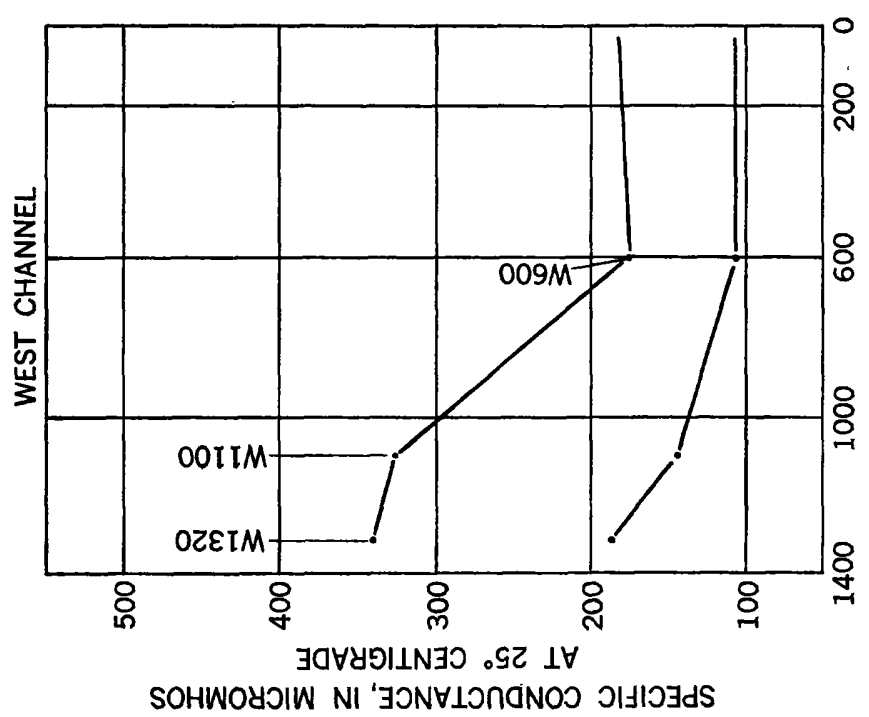

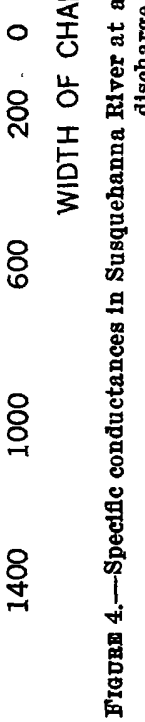


parison of the specific conductances compiled in table $\varepsilon$ indicates that this same relation occurs for maximum, average, and minimum observed values and, thus, probably occurs at most discharge rates.

\section{ENVIRONMENT AND CHEMICAL QUALITY}

The chemical character of the Susquehanna River at Harrisburg is influenced by three major factors: streamflow, anthracite and bituminous coal-mine drainage, and geology. Most of the tri "itaries draining into the west side of the river contain high concentrations of calcium and bicarbonate ions, in relation to other constituents. Many of the tributaries on the east side contain high concentrations of calcium and sulfate ions. The incomplete mixing of the calcium bicarbonate and calcium sulfate waters produces the cross-section variations at Harrisburg.

A map of the central Susquehanna River basin showing many of the tributaries and sampling points is presented in figure 5 .

\section{STREAMFLOW}

Streamflow is composed of water that reaches the stream by direct overland flow and by ground-water inflow. After periods of moderate to heavy precipitation, the major part of the water flowing in a stream is the result of direct overland flow. Base flow is composed largely of ground-water inflow. During periods of base flow, the dissolved-solids content of the Susquehanna River is at a maximum, as the chemical quality of the river represents the ef 'sct of groundwater inflow and coal-mine drainage. As streamflow increases, the dissolved-solids content is lowered by dilution from direct runoff. The decrease in dissolved-solids content with increase in flow can be shown using the specific conductance of station E. 118' as a measurement of the dissolved-solids content. During the period 1956-60, the maximum specific conductance, based on a once-a-month sampling, was 391 micromhos on September 16, 1957, and the dircharge on this date was 3,580 cfs. On February 15, 1960, the specific conductance was 96 micromhos, and the discharge was 91,000 cfs.

\section{COAL-MINE DRAINAGE}

Several tributaries to the Susquehanna River, upstr $3 a m$ from Harrisburg, receive coal-mine drainage. The headwaters of the West Branch Susquehanna and Juniata Rivers receive coal-mine drainage from the bituminous coal fields in western Pennsylvania. The Nescopeck, Catawissa, Shamokin, Mahanoy, and Manhantango Creeks and Lackawanna River receive coal-mine drainage from the anthracite coal fields in the northeastern part of the Common wealth. 


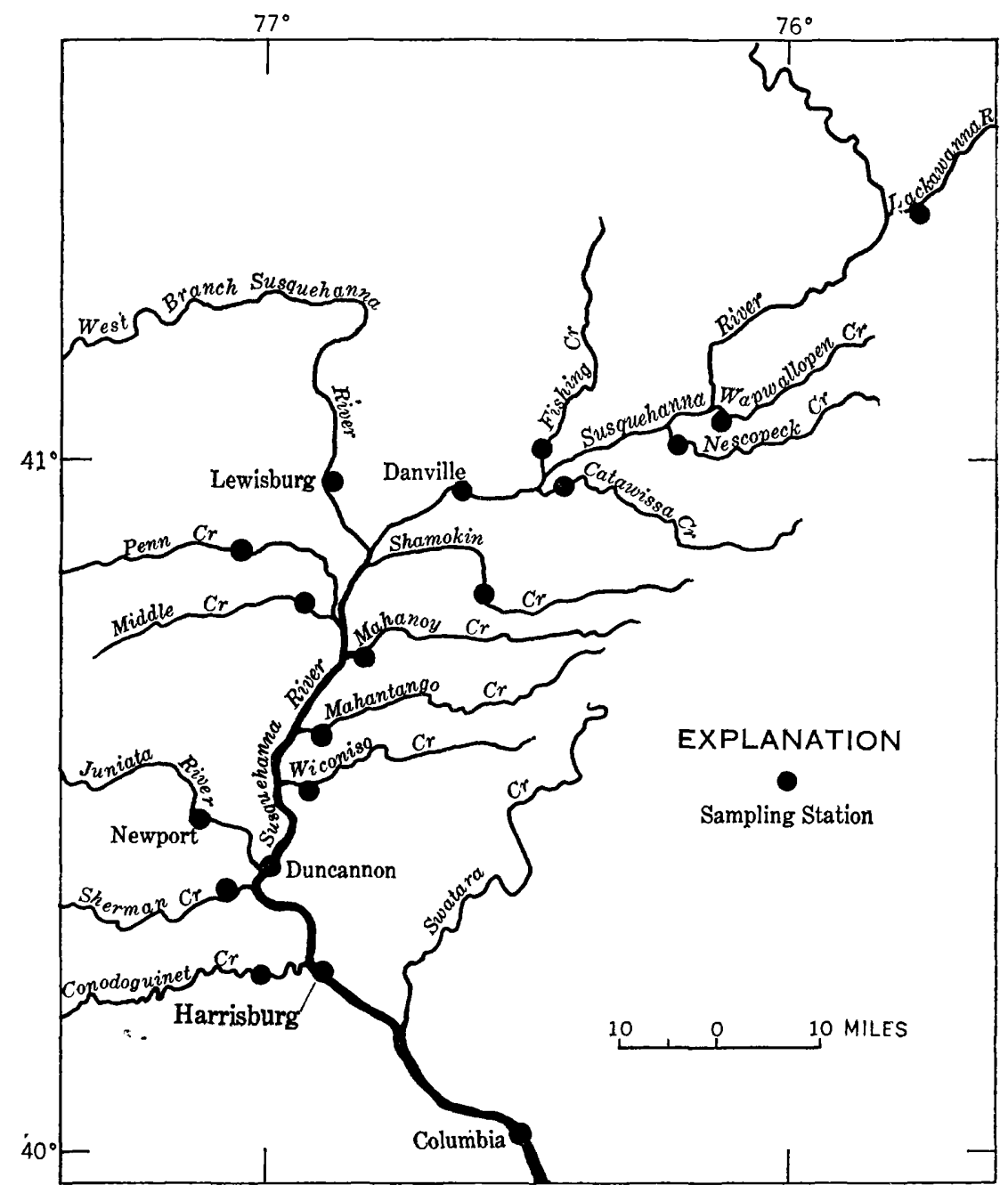

Frgore 5.-Map of the central Susquehanna River basin.

The chemical quality of streams receiving water drained from coal mines are strongly influenced by the composition and concentration of the coal-mine drainage. As shown by analyses of mine effluents from the anthracite coal fields in table 3, coal-mine effluents are low in $\mathrm{pH}$ (below 5.0) and high in iron (above $1.0 \mathrm{ppm}$ ), marganese, aluminum, sulfate, and free sulfuric acid content. Accordingly, the dissolved-solids contents of the tributaries draining the anthracite coal regions range between 100 and $3,000 \mathrm{ppm}$, depending on the amount and concentration of coal-mine effluents that are purnped or seep into the streams in relation to their total flow. 
TABLE 3.-Physical and chemical character of mine drainage from anthracite coal fields

[Analyses by U.S. Geol. Survey. Samples collected June 25, 1959]

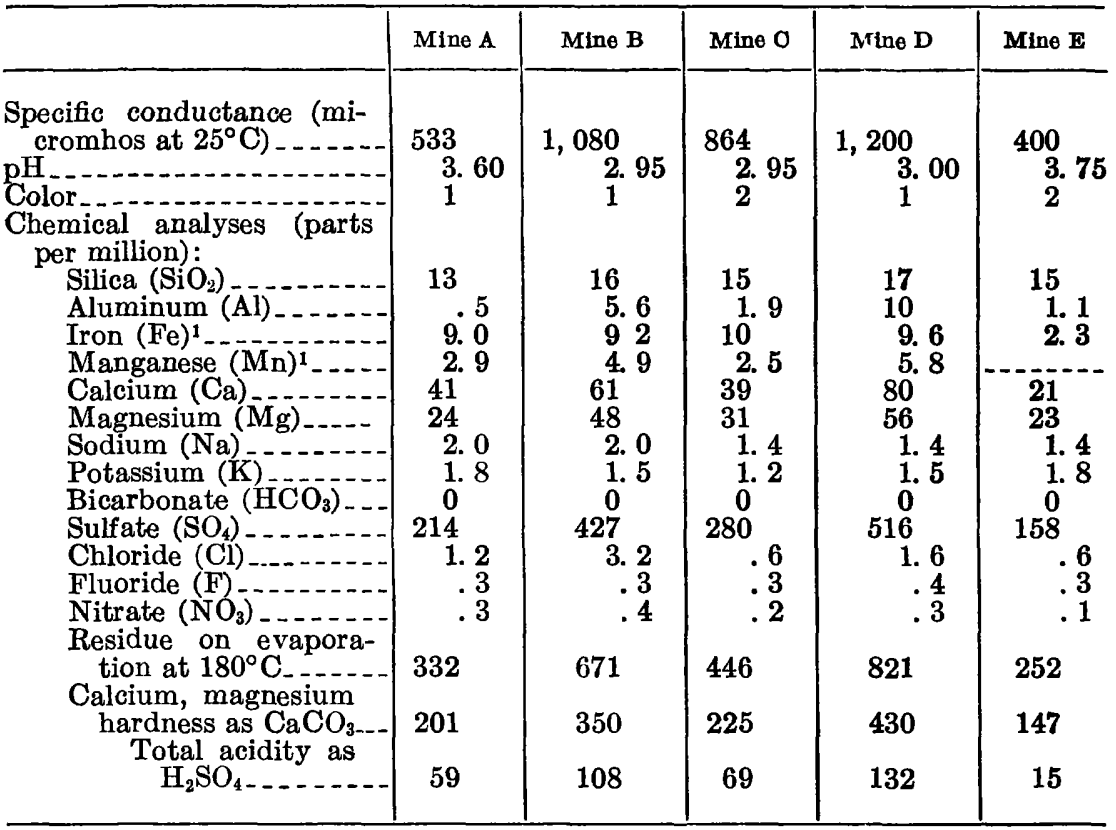

It time of sampling.

Chemical analyses of water from the principal tributaries to the Susquehanna River above the Harrisburg station are given in table 4. The tributaries were usually sampled near their conf uence with the Susquehanna River. The sampling locations are plotter on the map of the Susquehanna River basin (fig. 5). The bicarbonate-ion concentrations of the eastern tributaries range from 0 to $28 \mathrm{pp}$, and the sulfate-ion concentrations range from 10 to $925 \mathrm{ppm}$. The concentrations of bicarbonate ion in the western tributaries range from 12 to 160 ppm and of sulfate ion from 8.6 to $65 \mathrm{ppm}$.

Bar diagrams of sulfate and bicarbonate-ion concentrations (fig. 6) show that, with the exception of Wapwallopen Creek, the sufate-ion concentration exceeds the bicarbonate-ion concentartion for each of the eastern tributaries. The sulfate-ion concentration exceeds the bicarbonate-ion concentration in only one of the western tributaries, the West Branch Susquehanna River. Coal-mine drainage caused this high sulfate-low bicarbonate relation in these streams. 


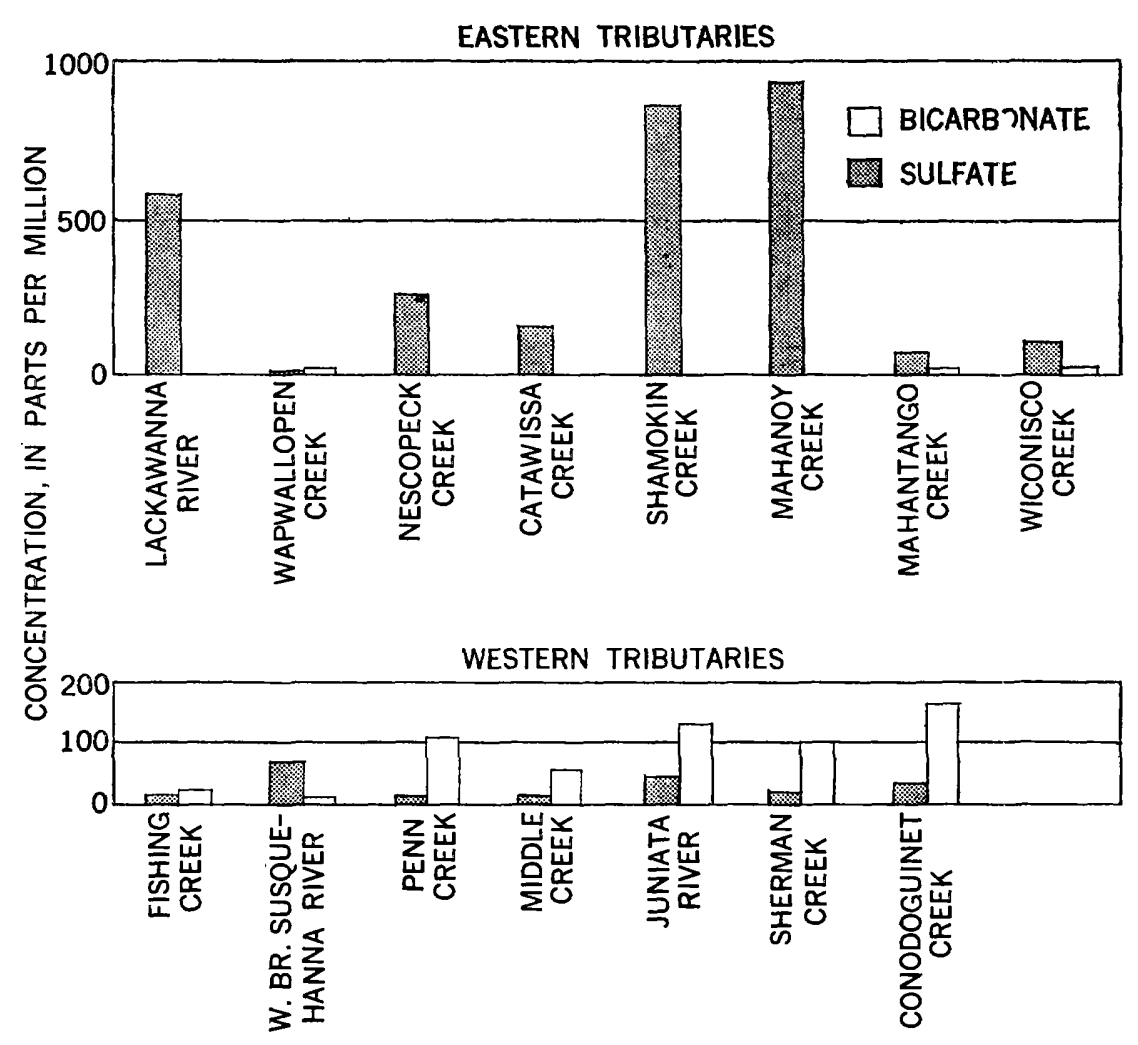

I'xGURE 6.-Sulfate- and bicarbonate-1on concentrations in the principal tributaries of the Susquehanna River. 
TABLE 4.-Chemical analyses, in parts per million, at sampling stations in the Susquehanna River basin, Pennsylvania

[Analyses by U.S. Geol. Survey]

\begin{tabular}{|c|c|c|c|c|c|c|c|}
\hline \multirow{2}{*}{ Stream } & \multirow{2}{*}{ Date } & \multirow{2}{*}{$\begin{array}{c}\text { Bicar- } \\
\text { bonate } \\
(\mathrm{HCO})\end{array}$} & \multirow[b]{2}{*}{$\begin{array}{c}\text { Sulfate } \\
\left(\mathrm{SO}_{4}\right)\end{array}$} & \multicolumn{2}{|c|}{ Hardness as $\mathrm{CaCO}$. } & \multirow{2}{*}{$\begin{array}{l}\text { Specific } \\
\text { conduct- } \\
\text { ance } \\
\text { (mlero- } \\
\text { mhos } \\
\text { at } 25^{\circ} \mathrm{C} \text { ) }\end{array}$} & \multirow{2}{*}{ pH } \\
\hline & & & & $\begin{array}{c}\text { Calcium, } \\
\text { mag- } \\
\text { nesium }\end{array}$ & $\begin{array}{c}\text { Non } \\
\text { car- } \\
\text { bonat; }\end{array}$ & & \\
\hline $\begin{array}{l}\text { Lackawanna River } \\
\text { Wapwallopen Creek } \\
\text { Nescopeck Creek } \\
\text { Fishing Creek } \\
\text { Catawissa Creek. } \\
\text { West'Branch Susquehanna }\end{array}$ & $\begin{array}{r}8-25-60 \\
6-23-50 \\
6-23-50 \\
10-11-57 \\
10-22-59\end{array}$ & $\begin{array}{r}0 \\
16 \\
0 \\
20 \\
0\end{array}$ & $\begin{array}{r}573 \\
10 \\
262 \\
12 \\
150\end{array}$ & $\begin{array}{r}530 \\
18 \\
154 \\
22 \\
87\end{array}$ & $\begin{array}{r}530 \\
5 \\
154 \\
6 \\
87\end{array}$ & $\begin{array}{r}1,080 \\
47 \\
650 \\
73 \\
349\end{array}$ & $\begin{array}{l}3.75 \\
6.6 \\
3.90 \\
6.2 \\
3.95\end{array}$ \\
\hline $\begin{array}{l}\text { River } \\
\text { Shamokin Creek } \\
\text { Penn Creek } \\
\text { Middle Creek } \\
\text { Mahanoy Creek } \\
\text { Mahantango Creek } \\
\text { Wiconisco Creek } \\
\text { Juniata River } \\
\text { Sherman Creek } \\
\text { Conodoguinet Creek }\end{array}$ & $\begin{array}{r}8-9-60 \\
10-7-59 \\
10-8-59 \\
4-19-60 \\
6-23-50 \\
6-23-50 \\
10-23-59 \\
8-1-60 \\
10-21-59 \\
10-12-57\end{array}$ & $\begin{array}{r}12 \\
0 \\
103 \\
56 \\
0 \\
6 \\
28 \\
126 \\
99 \\
160\end{array}$ & $\begin{array}{c}65 \\
853 \\
12 \\
8.6 \\
925 \\
62 \\
102 \\
43 \\
16 \\
27\end{array}$ & $\begin{array}{r}72 \\
700 \\
86 \\
50 \\
709 \\
108 \\
128 \\
136 \\
97 \\
136\end{array}$ & $\begin{array}{r}62 \\
700 \\
2 \\
4 \\
7139 \\
61 \\
175 \\
33 \\
16 \\
5\end{array}$ & $\begin{array}{r}189 \\
1,730 \\
195 \\
120 \\
1,620 \\
179 \\
299 \\
315 \\
198 \\
350\end{array}$ & $\begin{array}{l}6.4 \\
3.00 \\
7.4 \\
8.0 \\
3.90 \\
4.9 \\
6.4 \\
7.6 \\
7.1 \\
7.2\end{array}$ \\
\hline
\end{tabular}

Chemical analyses of water samples from cross-section locations on the Susquehanna River above and below Harrisburç are tabulated in table 5. These samples were collected during a low discharge (14,800 cfs at Harrisburg) so that the variation in chernical character of the cross section would be maximized.

The chemical analyses of water samples from cross-sestion locations on the Susquehanna River at Danville and near Duncannon (table 5) show the effect of mine drainage from the Lackawanna River and the Nescopeck, Catawissa, Shamokin, Mahanoy, Mahantango Creeks. The sulfate-ion concentration increases in a west to east direction. This increase is further evidence of the pattern of higher sulfate-ion concentrations and lower $\mathrm{pH}$ 's on the east side of the cross sections as a result of the coal-mine drainage from the anthracite coal fields into the eastern tributaries (fig. 6) of the Susquehanna River. The pattern is retained in the east channel stations of the Harrisburg cross sections (fig. 3 ). 
TABLE 5.-Chemical analyses, in parts per million, at cross-section sampling locations on the Susquehanna River in Pennsylvania, collected July 19, 1961

[Analyses by U.S. Geol. Survey]

\begin{tabular}{|c|c|c|c|c|c|c|}
\hline \multirow{2}{*}{ Station } & \multirow{2}{*}{$\begin{array}{c}\text { Bicar- } \\
\text { bonate } \\
\text { (HCOs) }\end{array}$} & \multirow[b]{2}{*}{$\begin{array}{l}\text { Sulfate } \\
\text { (SOI) }\end{array}$} & \multicolumn{2}{|c|}{ Hardness as $\mathrm{CaCO}_{3}$} & \multirow{2}{*}{$\begin{array}{c}\text { Specific } \\
\text { conduct- } \\
\text { ance } \\
\text { (micro- } \\
\text { mhos } \\
\text { st } 25^{\circ} \mathrm{C} \text { ) }\end{array}$} & \multirow{2}{*}{ pH } \\
\hline & & & $\begin{array}{c}\text { Calcium } \\
\text { mag- } \\
\text { nesium }\end{array}$ & $\begin{array}{c}\text { Non- } \\
\text { carbonate }\end{array}$ & & \\
\hline \multicolumn{7}{|l|}{ Danville: } \\
\hline West side_ & 62 & 69 & 120 & 69 & 290 & 7. 2 \\
\hline West center & 67 & 82 & 132 & 76 & 317 & 7. 2 \\
\hline Center. & 62 & 85 & 136 & 85 & 332 & 7. 2 \\
\hline East cente & 58 & 90 & 134 & 87 & 328 & $7 . \overline{5}$ \\
\hline East side_. & 50 & 91 & 128 & 87 & 310 & 7.1 \\
\hline \multicolumn{7}{|l|}{ Duncannon: } \\
\hline West side & 36 & 54 & 80 & 51 & 196 & 7.2 \\
\hline West center & 29 & 67 & 94 & 70 & 228 & 6.7 \\
\hline Center. & 58 & 69 & 118 & 71 & 291 & 7. 1 \\
\hline East center. & 65 & 80 & 130 & 77 & 329 & 7. 1 \\
\hline East side & 20 & 206 & 220 & 204 & 493 & 6. 7 \\
\hline \multicolumn{7}{|l|}{ Harrisburg: } \\
\hline West 1320 & 156 & 19 & 160 & 32 & 313 & 7. 9 \\
\hline West 1100 . & 94 & 33 & 106 & 29 & 241 & 7.8 \\
\hline West 600 & 44 & 52 & 84 & 48 & 201 & 7. 3 \\
\hline East 1180 & 34 & 66 & 88 & 60 & 217 & 7. 1 \\
\hline East 600 & 59 & 82 & 124 & 76 & 302 & 7. 1 \\
\hline East 120 & 34 & 140 & 168 & 140 & 399 & 6.9 \\
\hline \multicolumn{7}{|l|}{ Columbia: } \\
\hline West side_... & 73 & 50 & 106 & 46 & 253 & 7. 3 \\
\hline West center. - & 69 & 52 & 104 & 48 & 251 & 7. 2 \\
\hline Center........ & 60 & 66 & 112 & 63 & 267 & 7. 5 \\
\hline East center & 56 & 82 & 128 & 82 & 296 & 7. 2 \\
\hline East side & 61 & 93 & 144 & 94 & 335 & 7. 0 \\
\hline
\end{tabular}

The effect of coal-mine drainage (high sulfate concentrations and low $\mathrm{pH}$ ) from the bituminous coal fields in western Penns:"lvania on the chemical quality of the Susquehanna River at Harrisburg is not so pronounced as is the effect of the anthracite fields on eastern tributaries. Neutralization and dilution of streams draining the bituminous coal fields by tributaries draining limestone and dolomite regions in south-central Pennsylvania retard the effect of acid mine drainage.

The effect of coal-mine drainage on the chemical quality of water is more pronounced on the West Branch Susquehanna River than on the Juniata River (table 4). At the Lewisburg sampling station (fig. 5) on the West Branch Susquehanna River, the concentration of the sulfate ion generally exceeds the bicarbonate ion, but at the Newport sampling station on the Juniata River the bicarbonate ion exceeds the sulfate ion (table 4). Durfor and Anderson (1963) reported that for the period 1944-52 the average sulfate-ion concentration at the Lewisburg station was $50 \mathrm{ppm}$, althorgh the average bicarbonate-ion concentration was $10 \mathrm{ppm}$. For the same 
period, the average sulfate-ion concentration at the Newport station was $41 \mathrm{ppm}$, though the average bicarbonate-ion concentration was $72 \mathrm{ppm}$.

\section{GEOLOGIC INFLUENCES}

Both the eastern and the western tributaries of the Susquehanna River in the vicinity of Harrisburg are underlain by limestone and dolomite formations and by glacial-drift deposits. Each geologic environment influences the chemical character of the stream. The limestone and dolomite influence the chemical quality because of their position in valley bottoms and their soluble nature. The glacialdrift deposits blanket the uplands in northeastern Pennsylvania. Many of the streams draining the glaciated part flow over buried valleys filled with glacial-outwash deposits. Trase deposits are permeable and are hydraulically connected to underlying formations.

With few exceptions, calcium-bicarbonate type of water predominates in the tributaries draining into the west side of the Susquehanna River. These tributaries drain regions urderlain by limestone and dolomite formations or by glacial-drift deposits. Hence, streams draining these regions are generally alkaline ( $\mathrm{pH}$ 6.0-8.5) and high in calcium, magnesium, and bicarbonate-ion concentration, in relation to other constituents. Concentrations of calcium, magnesium, and bicarbonate ions and $\mathrm{pH}$ are lower in streams draining the glacial-drift areas in the northern part of the basin than in the limestone terranes. Chemical analyses of several western tributaries are presented in table 4 to show chemical quality of the streams draining into the west side of the Susquehanna Rirer above Harrisburg. Figure 6 is a graphical illustration of the sulfate and bicarbonate-ion concentrations for the various tributaries named in table 4.

The bicarbonate-ion concentration at the Harrisburg station W. 1320 is considerably higher ( $156 \mathrm{ppm})$ than the concentrations at the west side stations at Danville $(62 \mathrm{ppm})$ or near Duncannon $(36 \mathrm{ppm})$. The Duncannon station is just above the confluence of the Juniata River. The higher bicarbonate-ion concentrations at station $W .1320$ may be due to the high concentration of bicarbonate in the v7ater of the Juniata River and the Conodoguinet Creek (fig. 4).

Most of the tributaries that drain into the east side of the river receive coal-mine drainage, and geologic influences do not predominate. Wapwallopen Creek, an exception, drains an area of glacial drift overlying sandstone and shale but does not receive coal-mine drainage. It is low in dissolved solids and generally is higher in bicarbonate-ion concentration than in sulfate-ion concentration (fig. 6). 


\section{CONCLUSIONS}

The chemical quality of cross-section samples collected near the west bank at Harrisburg closely resembles the water of the e' River and Conodoguinet Creek, which drain the limestone tarranes to the west of the Susquehanna River. These streams tend to entrain along the west bank of the Susquehanna River and to carry water high in $\mathrm{pH}$ and in calcium, magnesium, and bicarbonate-ion concentrations.

Water in the center of the Harrisburg station generally resembles the chemical character of the West Branch Susquehanna River, as its dissolved-solids content is low in relation to other sections of the river, and its sulfate-ion concentration generally exceeds the bicarbonate-ion concentration.

Water sampled near the east or Harrisburg bank shows the in fluence of coal-mine drainage. River water from east channel station E. 120 is high in sulfate-ion concentration (36-301 ppm) and ranges in $\mathrm{pH}$ from slightly acid to slightly alkaline (5.7-7.5).

Although the long distance involved, the many islands and bridge piers, and the rocky streambed favor mixing of the Susquahanna River flow, the chemical composition of water at the Harrisburo cross section indicates that the principal tributaries above Harrisburg do not intermix sufficiently to lose their identity before reaching Harrisburg. In fact, the cross-section variations in chemical comfosition of the water at the Harrisburg station are retained at Columbia, several miles downstream from the Harrisburg station. This lack of lateral mixing probably is due to the very small depth-width ratio and also to the extreme width of the river. The river at median flow at the Harrisburg sampling station ranges between 3.9 and 9.3 feet deep and is approximately 3,000 feet or slightly more than half a mile wide.

\section{REFERENCES}

Beamer, N. H., 1953, Chemical character of surface water in Pennsvlvania, 1949-51: Pennsylvania Dept. Commerce, State Planning Board.

Durfor, C. N., and Anderson, P. W., (1963), Chemical quality of surface waters in Pennsylvania: U.S. Geol. Survey Water-Supply Paper 1619-W, V71-W50.

Rainwater, F. H., and Thatcher, L. L., 1960, Methods for collection and analysis of water samples: U.S. Geol. Survey Water Supply Paper 1454, 301 p.

White, W. F., Jr., 1947, Industrial utility of water in Pennsylvania, Chemical character of surface water, 1944-46: Pennsylvania Dept. Commerce. State Planning Board.

1949, Chemical quality of industrial surface waters of Penns, 7 lvania: Paper prepared for presentation at the Tenth Annual Water Conference of the Engineers' Society of Western Pennsylvania.

1951, Chemical character of surface water in Pennsylvania, 1946-49: Pennsylvania Dept. Commerce, State Planning Board. 


